Thorax (1972), 27, 315.

\title{
Mottled chest radiograph and gas transfer defect in chronic liver disease
}

\author{
N. N. STANLEY and D. J. WOODGATE2 \\ Departments of Medicine and Cardiology, The Royal Free Hospital, London N.W.3
}

In a prospective study of 170 patients with various types of chronic liver disease, a pulmonary gas transfer defect was found in $20 \%$ and mottled shadowing in the chest radiograph in $6 \%$. The presence of these abnormalities was not related to the cause of the liver disease.

Reduction of transfer factor in liver disease was not accompanied by a restrictive ventilatory defect and was found in most cases with mottled radiographs.

The incidence of finger clubbing and the levels of both venoarterial admixture and cardiac output were higher in patients with mottling than in those with normal radiographs. Mottling was also seen in the chest radiographs of five other patients with hepatic cirrhosis who had previously been investigated for cyanosis due to intrapulmonary shunting.

Despite earlier reports of active chronic hepatitis and primary biliary cirrhosis occurring in patients with fibrosing alveolitis, we suggest that these radiographic changes in liver disease are usually caused by a pulmonary vascular disorder, rather than by coincidental lung disease, and are a local manifestation of a generalized vasodilated state. The low incidence of diffuse lung disease complicating chronic liver disease was confirmed by reviewing the hospital necropsy records.

In one patient the radiographic mottling disappeared and the physiological evidence of a circulatory disorder became less marked during a period of improved hepatocellular function.

Some of the cardiorespiratory disorders in chronic liver disease (CLD) have received considerable attention. They include hypoxaemia due to intrapulmonary arteriovenous shunts (Rydell and Hoffbauer, 1956), increased cardiac output (Kowalski and Abelmann, 1953), respiratory alkalosis (Vanamee et al., 1956), and pulmonary hypertension (Senior et al., 1968). It is less well known that mottled shadows may sometimes be seen at the lung bases on chest radiographs (Chrispin and Lessof, 1965); post-mortem studies have suggested that these are due to dilated precapillary pulmonary blood vessels (Berthelot, Walker, Sherlock, and Reid, 1966). Isolated cases of CLD have also been reported with reduced pulmonary transfer factor (Karlish, Marshall, Reid, and Sherlock, 1967; Cotes, Field, Brown, and Read, 1968; El Gamal, Stoker, Spiers, and Whitaker, 1970). Radiographic mottling and gas transfer defect are both characteristic features of diffuse lung disease and it has recently been reported that fibrosing alveolitis is occasionally associated with both active chronic

1Present address: Hospital of the University of Pennsylvania, Philadelphia, Pa. 19104, U.S.A.

2Present address: St. Andrew's Hospital, Billericay, Essex. hepatitis (Turner-Warwick, 1968) and primary biliary cirrhosis (Mason, McIllmurray, Golding, and Hughes, 1970).

We present in this paper the results of pulmonary investigations in 170 patients with CLD. Special attention is given to the physiological findings in CLD with mottled chest radiographs and these are compared with the physiological pattern seen in diffuse lung disease. The incidence of diffuse lung disease in CLD was also determined by use of hospital necropsy records.

\section{MATERIALS AND METHODS}

We investigated 170 patients with CLD who had not been assessed from a respiratory viewpoint beforehand (the prospective study). The diagnosis of the liver disorder had been based on the clinical picture, liver biopsy, and immunological status. Seventy-three had active chronic hepatitis, 37 primary biliary cirrhosis, and 27 alcoholic cirrhosis; 33 had cirrhosis which was cryptogenic or of other aetiology. Cases with severely decompensated liver disease, ascites or chronic bronchitis were excluded. Clinical evidence of a pulmonary disturbance was sought by a full history and physical examination of the chest. Dyspnoea was graded according to the revised Medical Research 
Council's questionnaire on respiratory symptoms ${ }^{1}$. Recent chest radiographs were studied with the patients' identities concealed from the examiner. Vital capacity (VC) was measured by a dry spirometer (Vitalograph). Pulmonary transfer factor for carbon monoxide (TF) was measured by the single breath method of Ogilvie, Forster, Blakemore, and Morton (1957) modified by using the calculation of breathholding time proposed by Jones and Meade (1961) and of alveolar volume from the dilution of helium by the test breath. Measured values of TF were corrected for the effect of anaemia by the regression formula of Dinakara et al. (1970).

Twenty-six patients with CLD consented to further physiological investigations after a full explanation of their nature and purpose. Details of these procedures are given elsewhere (Stanley and Woodgate, 1971). In brief, simultaneous collections were made of arterial blood, mixed venous blood, and expired air while breathing air and oxygen successively in the supine position. Gasometric analysis of these samples allowed determination of the alveolar-arterial $\mathrm{O}_{2}$ differences $\left(\mathrm{A}-\mathrm{aDO}_{2}\right)$ by the alveolar air equation, cardiac output $(\mathrm{Qt})$ by the Fick principle, and venoarterial admixture $(\mathrm{Qva})$ by the standard shunt formula.

For comparison VC, TF, A- $\mathrm{aDO}_{2}$, and Qva were determined in eight successive patients attending this hospital with diffuse lung disease; four had fibrosing alveolitis and four had pulmonary sarcoidosis. Mixed venous blood was not sampled in these subjects, but an arteriovenous $\mathrm{O}_{2}$ difference of 4.5 vol $\%$ was
assumed for the calculation of $\mathrm{Qva}$.

$\mathrm{VC}$ and TF were expressed as percentages of the predicted values for the patients' heights and ages $\underline{\underline{D}}$ given by Cotes (1968). Approximate $95 \%$ confidence $\frac{\bar{\rho}}{7}$ limits for these measurements were set by the use of $\mathbb{Q}$ Cotes' estimates of their standard deviations in healthy subjects. Thus, normal ranges for VC and TF were ${ }^{\infty}$ assumed to be $75-125 \%$ and $70-130 \%$ of the predicted $\vec{O}$ values respectively. The mean VC and TF of $20-$ normal control subjects studied in this laboratory $\vec{\omega}$ were $99 \%$ and $101 \%$ of these predicted values. Gasometric data obtained in 14 healthy volunteers, whose $\vec{x}$ mean age was 42 years, were also used to establish î the following normal ranges: arterial $\mathrm{Po}_{2}$ 78-106. $\mathrm{mmHg}, \mathrm{A}-\mathrm{aDO}_{2}$ breathing ambient air less than $25 \omega$ $\mathrm{mmHg}$, and Qva less than $3 \%$ of the cardiac output.

We also reviewed the radiographs and physiological data of five patients with hepatic cirrhosis previously seen at our hospital who had been investigated for severe arterial unsaturation (the retrospective study). 3

The necropsy records provided information on the pulmonary histology of 120 patients with CLD who $\overrightarrow{0}$ died during the period 1965-70. They included 32 with active chronic hepatitis and 18 with primary biliary cirrhosis: their lung sections were re-examined by light microscopy and evidence of fibrosing alveolitis was sought. These patients also included 11 whose lung function had been assessed in life, 10 in the prospec-0 tive study and one in the retrospective study.

'Obtainable from W. J. Holman, Ltd., Dawlish, Devon

T A B LE I

FINDINGS IN THE PROSPECTIVE STUDY

\begin{tabular}{|c|c|c|c|c|c|c|c|}
\hline \multirow{2}{*}{ Cause of CLD } & \multirow{2}{*}{$\begin{array}{l}\text { No. of } \\
\text { Cases }\end{array}$} & \multirow{2}{*}{$\begin{array}{l}\text { Mean } \\
\text { Age } \\
(y r)\end{array}$} & \multirow{2}{*}{ Dyspnoea } & \multirow{2}{*}{ Rales } & \multicolumn{2}{|c|}{ Low Transfer Factor } & \multirow{2}{*}{$\begin{array}{c}\text { Mottled } \\
\text { Chest } \\
\text { Radiograph }\end{array}$} \\
\hline & & & & & $\begin{array}{l}\text { (uncorrected } \\
\text { for anaemia) }\end{array}$ & $\begin{array}{c}\text { (corrected } \\
\text { for anaemia) }\end{array}$ & \\
\hline $\begin{array}{l}\text { Active chronic hepatitis } \\
\text { Primary biliary cirrhosis } \\
\text { Alcoholic cirrhosis } \\
\text { Other causes of cirrhosis }\end{array}$ & $\begin{array}{l}73 \\
37 \\
27 \\
33\end{array}$ & $\begin{array}{l}38 \\
54 \\
50 \\
49\end{array}$ & $\begin{array}{l}13(18 \%) \\
12(32 \%) \\
5(19 \%) \\
10(30 \%)\end{array}$ & $\begin{array}{l}\mathbf{0} \\
\mathbf{0} \\
\mathbf{0} \\
\mathbf{2}\end{array}$ & $\begin{array}{r}20(27 \%) \\
10(27 \%) \\
6(22 \%) \\
13(39 \%)\end{array}$ & $\begin{array}{l}15(21 \%) \\
7(19 \%) \\
5(18 \%) \\
8(24 \%)\end{array}$ & $\begin{array}{l}3 \\
2 \\
1 \\
3\end{array}$ \\
\hline Total & 170 & 46 & $40(23 \%)$ & 2 & $49(29 \%)$ & $35(20 \%)$ & 9 \\
\hline
\end{tabular}

TA B LE II

FINDINGS IN CASES OF CHRONIC LIVER DISEASE WITH MOTTLED CHEST RADIOGRAPHS PRESENTING IN THE PROSPECTIVE STUDY

\begin{tabular}{|c|c|c|c|c|c|c|c|c|c|c|c|}
\hline \multirow{2}{*}{$\begin{array}{l}\text { Case } \\
\text { No. }\end{array}$} & \multirow{2}{*}{$\begin{array}{l}\text { Age } \\
(y r)\end{array}$} & \multicolumn{2}{|c|}{ Liver Disease } & \multirow{2}{*}{$\begin{array}{l}\text { Dyspnoea } \\
\text { Grade }\end{array}$} & \multirow{2}{*}{ Clubbing } & \multirow{2}{*}{$\begin{array}{c}\text { Vital } \\
\text { Capacity } \\
\text { (\% predicted) }\end{array}$} & \multirow{2}{*}{$\begin{array}{c}\text { Transfer } \\
\text { Factor }^{1} \\
\text { (\% predicted) }\end{array}$} & \multirow{2}{*}{$\begin{array}{c}\text { Arterial } \mathbf{O}_{2} \\
\text { Tension } \\
(\mathrm{mmHg})\end{array}$} & \multirow{2}{*}{$\begin{array}{c}\text { Alv.-art. } \\
\mathrm{O}_{2} \text { Diff. } \\
\text { Breathing } \\
\text { Air (mmHg) }\end{array}$} & \multirow{2}{*}{$\begin{array}{c}\text { Cardiac } \\
\text { Index } \\
\left(1 / \mathrm{min} / \mathrm{m}^{2}\right)\end{array}$} & \multirow{2}{*}{$\begin{array}{c}\text { Venoarteria } \\
\text { Admixture } \\
\text { (\% cardiac } \\
\text { output) }\end{array}$} \\
\hline & & Cause & $\underset{(y r)}{\text { Duration }}$ & & & & & & & & \\
\hline $\begin{array}{l}1 \\
2 \\
3 \\
4 \\
5 \\
6 \\
7 \\
8 \\
9\end{array}$ & $\begin{array}{l}17 \\
26 \\
30 \\
56 \\
47 \\
59 \\
14 \\
48 \\
43\end{array}$ & $\begin{array}{l}\text { Fasciol. } \\
\text { ACH } \\
\text { Crypt. } \\
\text { Crypt. } \\
\text { PBC } \\
\text { Alc. } \\
\text { ACH } \\
\text { ACH } \\
\text { PBC }\end{array}$ & $\begin{array}{r}10 \\
12 \\
13 \\
6 \\
6 \\
13 \\
7 \\
8 \\
2\end{array}$ & $\begin{array}{l}1 \\
0 \\
1 \\
0 \\
0 \\
1 \\
0 \\
0 \\
1\end{array}$ & $\begin{array}{l}+ \\
+ \\
+ \\
+ \\
+ \\
+ \\
+ \\
+\end{array}$ & $\begin{array}{r}95 \\
80 \\
88 \\
97 \\
100 \\
122 \\
95 \\
92 \\
102\end{array}$ & $\begin{array}{l}54 \\
37 \\
38 \\
71 \\
86 \\
57 \\
61 \\
60 \\
68\end{array}$ & $\begin{array}{l}66 \\
85 \\
69 \\
66 \\
88 \\
67 \\
78 \\
84\end{array}$ & $\begin{array}{l}41 \\
27 \\
43 \\
40 \\
30 \\
43 \\
-\overline{23}\end{array}$ & $\begin{array}{l}6 \cdot 2 \\
8 \cdot 8 \\
5 \cdot 6 \\
5 \cdot 3 \\
6 \cdot 1 \\
4 \cdot 9 \\
= \\
\overline{3 \cdot 9}\end{array}$ & $\begin{array}{r}11 \cdot 0 \\
9 \cdot 2 \\
7 \cdot 3 \\
7 \cdot 3 \\
6 \cdot 2 \\
10 \cdot 8 \\
- \\
\overline{2 \cdot 1}\end{array}$ \\
\hline
\end{tabular}

Fasciol. = hepatic fascioliasis; $\mathrm{ACH}=$ active chronic hepatitis; Crypt. $=$ cryptogenic cirrhosis; PBC=primary biliary cirrhosis; $\mathrm{Alc} .=$ alcoholic $\sigma$

${ }^{1}$ Corrected for effect of anaemia 


\section{RESULTS}

THE PROSPECTIVE STUDY The findings are summarized in Table I. Dyspnoea was common, although usually mild (grade I). More severe dyspnoea (grades II to IV) was present in $5 \%$. Crepitations were heard in only two patients and on clinical grounds were attributed to heart failure rather than to lung disease. The measured levels of TF were low in $29 \%$ and in $20 \%$ after correction for anaemia. Mottled radiographs were seen in $6 \%$. The incidence of reduced TF and abnormal radiographs was not related to the type of liver disease: in particular, these disturbances were not more frequent in cases of active chronic hepatitis or primary biliary cirrhosis.

Findings in cases with mottled radiographs (Table II) A striking aspect of the liver disease was its long duration in most cases. Eight of these nine patients had clubbing, compared with an incidence of only $8 \%$ in the 161 patients with normal radiographs. Four were mildly dyspnoeic, but none had clinical evidence of lung disease. Erythrocyte sedimentation rate was variable but often normal. Abnormal immunological tests were found only when appropriate to the underlying liver disease.

Physiological comparisons between CLD and diffuse lung disease Reduction of TF in CLD was often marked in those with radiographic mottling (Fig. 1). Indeed, cases of CLD with abnormal radiographs could not be distinguished

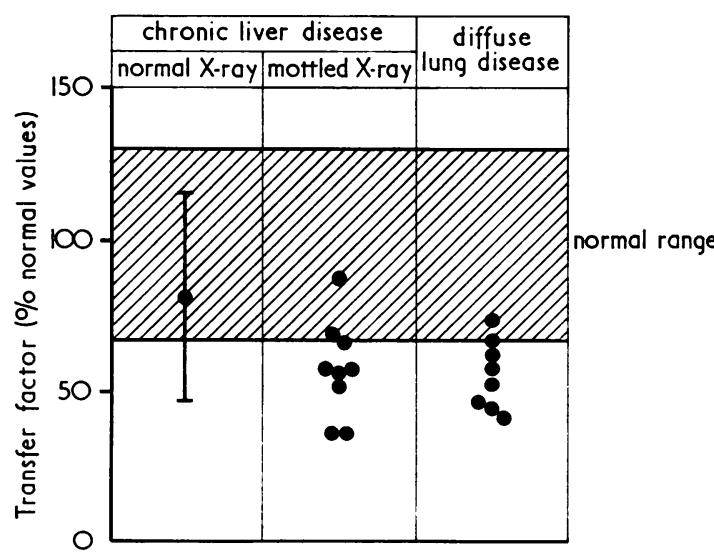

FIG. 1. Pulmonary transfer factor (TF) in cases of chronic liver disease, with normal or mottled chest radiographs, and in cases of diffuse lung disease. TF values are corrected for anaemia and their range is indicated by the mean value \pm $2 S . D$. in the cases of liver disease with normal radiographs. from cases of diffuse lung disease by measurement of TF. By contrast, VC was virtually normal in CLD irrespective of the radiographic appearance but tended to be low in cases of lung disease (Fig. 2).

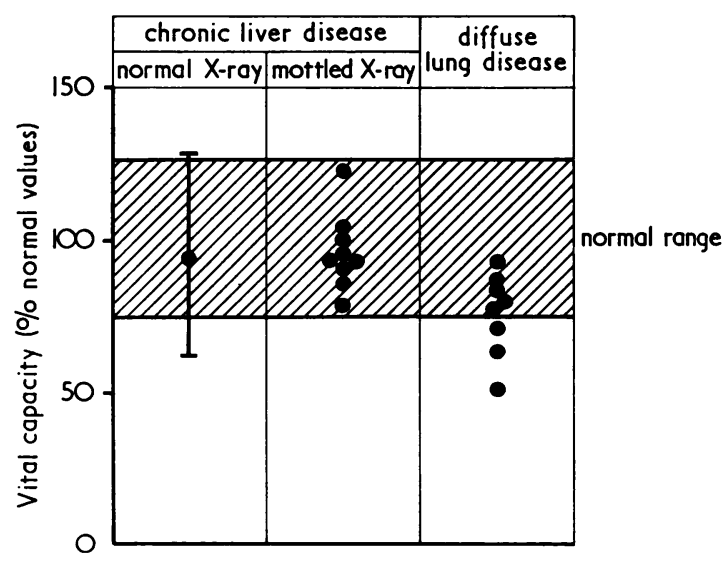

FIG. 2. Vital capacity (VC) in cases of chronic liver disease with normal or mottled chest radiographs, and in cases of diffuse lung disease. The range of $V C$ in cases of liver disease with normal radiographs is indicated by the mean value \pm 2 S.D.

The levels of arterial $\mathrm{Po}_{2}$ and $\mathrm{A}-\mathrm{aDO}_{2}$ in cases of CLD with mottled radiographs and patients with diffuse lung disease were similar (Fig. 3). Cardiac

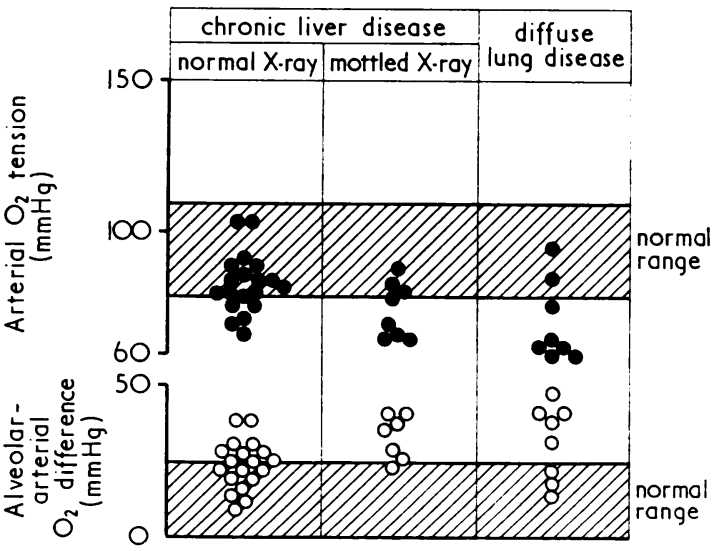

FIG. 3. Arterial $\mathrm{O}_{2}$ tensions and alveolar-arterial $\mathrm{O}_{2}$ differences breathing room air in cases of chronic liver disease with normal or mottled chest radiographs, and in cases of diffuse lung disease.

indices (Fig. 4) were usually higher in cases of CLD with mottled shadowing than in patients with 
a normal chest radiograph. An increase of Qva was common in CLD but was present in only one patient with diffuse lung disease (Fig. 5). However, it was especially striking that Qva was higher in six of the seven cases of CLD with mottled shadowing than in any of the other patients.

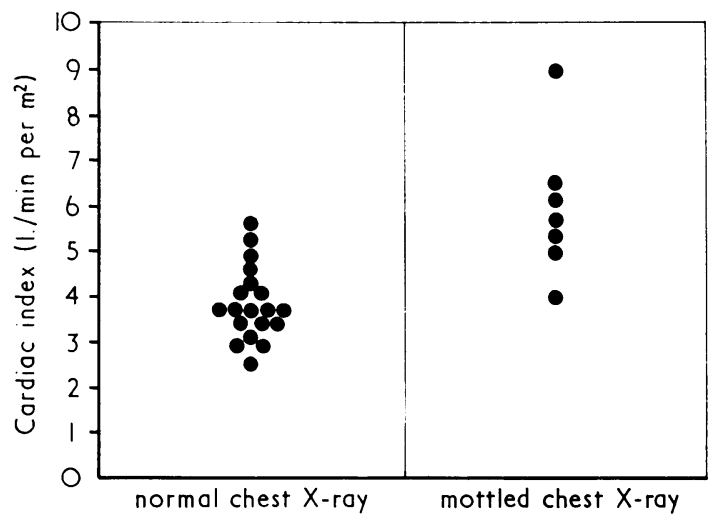

FIG. 4. Cardiac indices in cases of chronic liver disease with either normal or mottled chest radiographs.

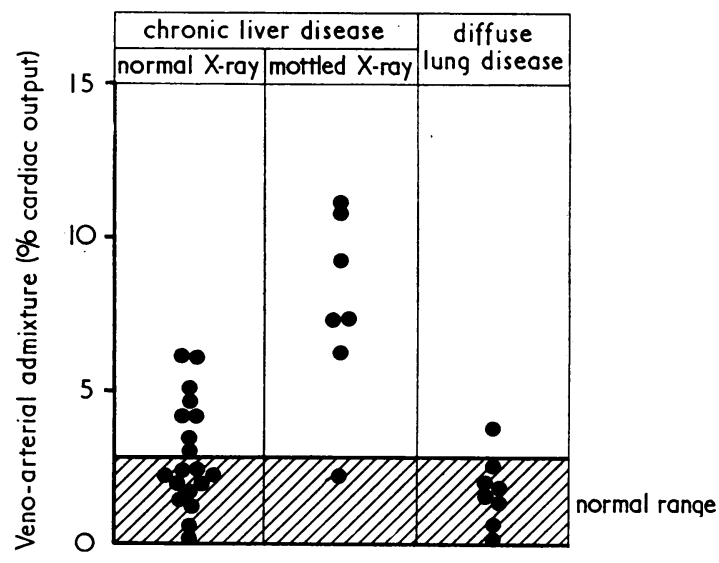

FIG. 5. Levels of venoarterial admixture in cases of chronic liver disease with normal or mottled chest radiographs, and in cases of diffuse lung disease.

cases of CLD revealed a wide variety of common $\vec{\theta}$ lung diseases, such as chronic bronchitis, emphy- N sema, and pneumonia, but no evidence of fibrosing alveolitis was seen. Two cases of primary biliary

T A B LE III

FINDINGS IN CASES OF CHRONIC LIVER DISEASE PRESENTING IN THE RETROSPECTIVE STUDY

\begin{tabular}{|c|c|c|c|c|c|c|c|c|}
\hline \multirow{2}{*}{$\begin{array}{l}\text { Case } \\
\text { No. }\end{array}$} & \multirow{2}{*}{$\begin{array}{c}\text { Age } \\
(\mathrm{yr})\end{array}$} & \multicolumn{2}{|c|}{ Liver Disease } & \multirow{2}{*}{$\begin{array}{c}\text { Dyspnoea } \\
\text { Grade }\end{array}$} & \multirow{2}{*}{$\begin{array}{c}\text { Vital } \\
\text { Capacity } \\
\text { (\% predicted) }\end{array}$} & \multirow{2}{*}{$\begin{array}{c}\text { Transfer } \\
\text { Factor }^{1} \\
\text { (\% predicted) }\end{array}$} & \multirow{2}{*}{$\begin{array}{c}\text { Arterial } \mathrm{O}_{2} \\
\text { Tension } \\
(\mathrm{mmHg})\end{array}$} & \multirow{2}{*}{$\begin{array}{c}\text { Venoarterial } \\
\text { Admixture } \\
\text { (\% cardiac } \\
\text { output) }\end{array}$} \\
\hline & & Cause & $\begin{array}{c}\text { Duration } \\
\text { (yr) }\end{array}$ & & & & & \\
\hline $\begin{array}{l}10 \\
11 \\
12 \\
13 \\
14\end{array}$ & $\begin{array}{l}60 \\
33 \\
10 \\
35 \\
30\end{array}$ & $\begin{array}{l}\text { Alc. } \\
\text { Crypt. } \\
\text { Crypt. } \\
\text { Crypt. } \\
\text { ACH }\end{array}$ & $\begin{array}{r}2 \\
29 \\
8 \\
12 \\
8\end{array}$ & $\begin{array}{l}2 \\
2 \\
1 \\
1 \\
2\end{array}$ & $\begin{array}{r}99 \\
102 \\
95 \\
105 \\
100\end{array}$ & $\begin{array}{l}49 \\
38 \\
49 \\
34 \\
51\end{array}$ & $\begin{array}{c}52 \\
(84 \%)^{2} \\
46 \\
58 \\
43\end{array}$ & $\begin{array}{l}35 \\
38 \\
35 \\
15 \\
28\end{array}$ \\
\hline
\end{tabular}

${ }^{1}$ Corrected for effect of anaemia

$2 \%$ Arterial $\mathrm{O}$, saturation (measured by manometric Van Slyke apparatus)

$\mathbf{A C H}=$ active chronic hepatitis; Alc.=alcoholic cirrhosis; Crypt. =cryptogenic cirrhosis

THE RETROSPECTIVE STUDY The findings in the five patients previously investigated because of arterial desaturation are shown in Table III. The liver disease was of no particular aetiology but had usually been of long duration. Case 5 had chronic bronchitis and bronchiectasis, but the remaining four patients had no clinical evidence of lung disease although they all complained of dyspnoea. All had cyanosis, finger clubbing, and high levels of venoarterial admixture. Retrospective examination of their chest radiographs revealed mottling in every case. Although none had significant reduction of vital capacity, all had considerable impairment of gas transfer.

Histological study The necropsy findings of 120 cirrhosis had widespread intrapulmonary granulomas; marked radiographic mottling had been observed in one of these patients (case 9 in Table II) and full details will be reported elsewhere. Lung tissue was also available in a second case with $N$ mottling and a reduced TF (case 10 in Table III). N This showed panacinar emphysema which had not 0 been suspected clinically. However, this emphysema could not have produced the radiographic changes, although it was possibly responsible for the gas $\stackrel{?}{?}$ transfer defect. The pulmonary vessels had not 0 been injected and no useful comments could be made about their structure. No pulmonary disease was found in two other cases in whom values of TF below $60 \%$ of predicted normal had been measured during life. 
(a)

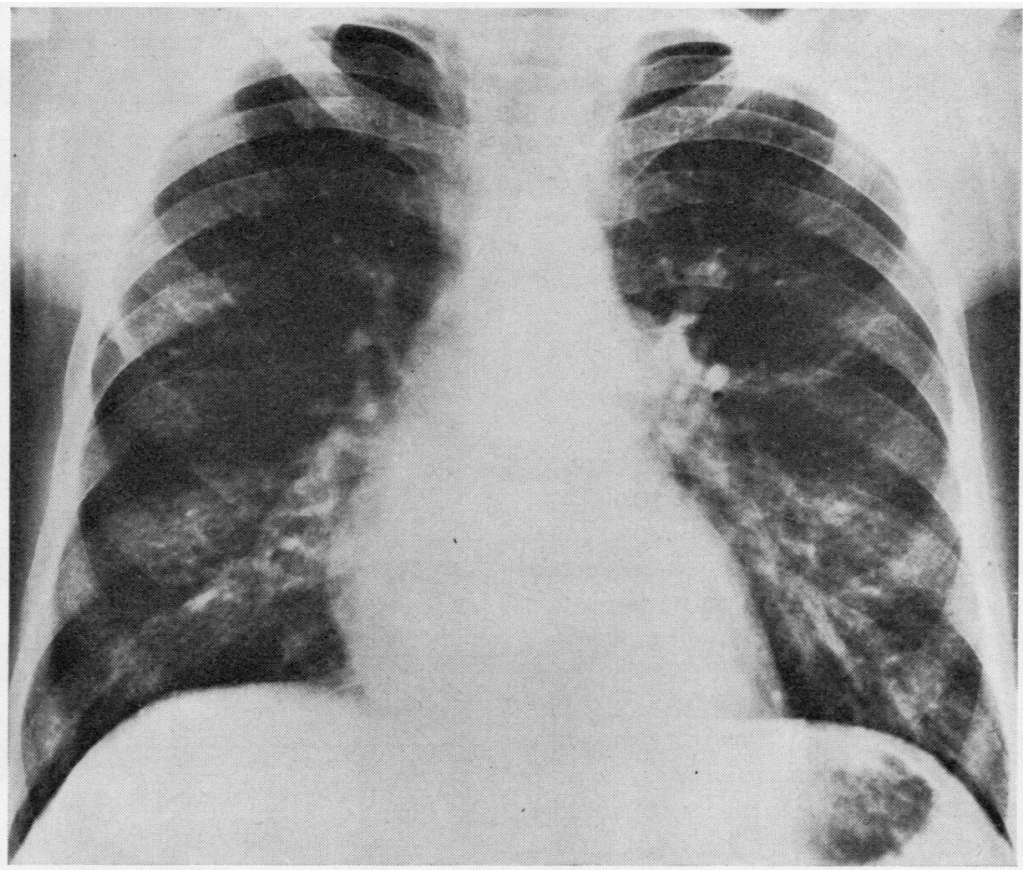

(b)

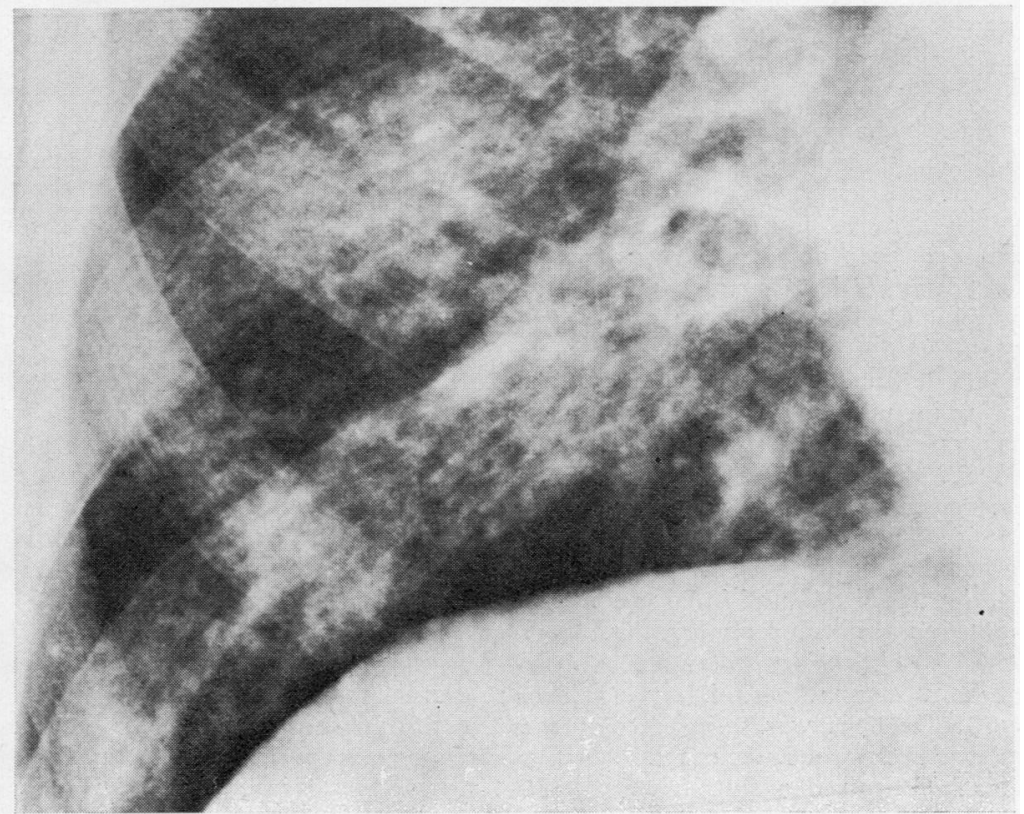

FIG. 6. Case 1. Chest radiographs (a) September 1968. There are coarse nodular shadows which are most marked in the right lower zone. The hilar vascular shadows are enlarged and the peripheral vascular markings are accentuated. (b) Detail of the right lower zone showing the nodular shadows. 
Chest radiographs The mottling was always bilateral with nodular shadows which were most pronounced in the lower lung zones, but in detail there were two distinct appearances. Usually the nodules were soft, coarse (1-4 mm), irregular, and superimposed on a clear background. An associated feature was accentuation of the pulmonary vessels both in the hilar regions and peripherally. The small vessels were especially prominent at the costophrenic angles where they often resembled septal lines, but linear shadows in this region could always be traced centrally to join other vessel markings and never extended laterally to touch the lung margin. These appearances were noted in cases 1 to 8 in the prospective study and in all the cases in the retrospective study. The most obvious changes of this type were seen in case 1 (Fig. 6a, b). A second type of shadowing was seen in case 9 of the prospective study. The nodules were much finer and in the right lower zone coalesced to form a ground-glass haze. The vascular markings were normal. She was the only case of CLD with nodular shadowing who had a normal level of cardiac index and venoarterial admixture. At necropsy she was found to have diffuse intrapulmonary granulomas.

\section{CASE REPORT}

Case 1 is reported in detail primarily to demonstrate that the radiographic shadowing and some of the associated physiological changes may resolve during clinical remission of the underlying liver disease. The case also shows that increased venoarterial admixture is not the sole cause of arterial hypoxaemia in CLD.

This young man had been admitted to hospital in 1959 when aged 7 years. He had hepatosplenomegaly and a blood eosinophilia of $15,000 / \mathrm{mm}^{3}$. Liver biopsy showed cirrhosis and infiltration of the portal tracts with eosinophils and lymphocytes. Investigations for a parasitic infestation including Fasciola hepatica were negative. A portacaval shunt was performed in 1961 for recurrent gastrointestinal bleeding. Finger clubbing and increased vascular markings on chest radiography were noted in 1964. The next year he developed precoma; he responded initially to a low protein diet, but in July 1968 he required additional neomycin therapy to prevent recurrent encephalopathy. Over this period (1964-68) his effort tolerance slowly deteriorated until he was unable to hurry on level ground. In September 1968 he was transferred to the Royal Free Hospital for further assessment.

Physical examination showed a small, icteric, and ill-looking youth. There was gross clubbing of the fingers and toes. His pulse ( $76 /$ minute) was bounding. Blood pressure $(110 / 65 \mathrm{mmHg})$ and venous pressure were normal. The second heart sound in the pulmonary area was accentuated but normally split. An ejection systolic murmur was audible over the whole praecordium. There was no peripheral oedema. Examination of the lungs was normal. The liver was enlarged, but the spleen was impalpable and there was no ascites.

Laboratory studies included the following: Haemoglobin $10 \cdot 8 \mathrm{~g} / 100 \mathrm{ml}$; WBC $17,500 / \mathrm{mm}^{3}$ with polymorphs 11,550, lymphocytes 4,900, monocytes 875 , and eosinophils 175; and ESR $116 \mathrm{~mm} /$ hour; total serum bilirubin $14 \mathrm{mg} / 100 \mathrm{ml}$, alkaline phosphatase $90 \mathrm{iu} / 1$, aspartate transaminase $90 \mathrm{iu} / 1$, albumin $1.8 \mathrm{~g} / 100 \mathrm{ml}$ and globulin $5.6 \mathrm{~g} / 100 \mathrm{ml}$. In the serum the Fasciola hepatica complement fixation test had become strongly positive (dilution 1:320). Chest radiography showed prominent hilar and peripheral vascular markings with widespread nodularity in both lower and middle lung zones (Figs. 6a, b). The electrocardiogram was normal.

Cardiorespiratory data are given in Table IV. Vital capacity was within normal limits, but transfer factor

T A B L E IV

CASE 1: CARDIOPULMONARY DATA

\begin{tabular}{|c|c|c|c|}
\hline & September 1968 & May 1970 & $\begin{array}{l}\text { Normal } \\
\text { Values }\end{array}$ \\
\hline $\begin{array}{l}\text { Chest radiograph } \\
\text { Transfer factor }{ }^{1} \\
\left(\mathrm{ml} / \mathrm{min} / \mathrm{mmHg}^{2} \mathrm{Hg}\right.\end{array}$ & $\begin{array}{l}\text { Heavy mottling } \\
12(16)\end{array}$ & $\begin{array}{l}\text { No mottling } \\
12(16)\end{array}$ & $29-33^{2}$ \\
\hline $\begin{array}{l}\text { Vital capacity } \\
(\mathrm{ml})\end{array}$ & 3,900 & 4,200 & $4,100-4,700^{\circ}$ \\
\hline $\begin{array}{l}\text { Arterial oxygen tension } \\
(\mathrm{mmHg})\end{array}$ & 66 & 73 & $>78$ \\
\hline $\begin{array}{l}\text { Alv.-art. } \mathrm{O}_{2} \text { difference } \\
\text { breathing air }(\mathrm{mmHg})\end{array}$ & 41 & 35 & $<25$ \\
\hline $\begin{array}{l}\text { Venoarterial admixture } \\
\text { (\% cardiac output) }\end{array}$ & 11 & 2 & $<3$ \\
\hline $\begin{array}{l}\text { Cardiac index } \\
\left(1 / \mathrm{min} / \mathrm{m}^{2}\right)\end{array}$ & $6 \cdot 2$ & $5 \cdot 4$ & $3 \cdot 6$ \\
\hline $\begin{array}{l}\text { Pulmonary arterial } \\
\text { pressure (mmHg) }\end{array}$ & $54 / 16$ & $48 / 16$ & $<32 / 13$ \\
\hline
\end{tabular}

Values in parentheses are corrected for effect of anaemia ${ }^{2}$ Lower values for 1968, higher values for 1970

was very low even after correction for anaemia (54\% predicted normal). A-aDo ${ }_{2}$ breathing room air was $41 \mathrm{mmHg}$. It was calculated that the venoarterial admixture was $11 \%$ of the cardiac output, which must have contributed a large part of the arterial hypoxaemia. Measurements of pressure and saturation at different sites during right heart catheterization revealed no evidence of congenital heart disease and the systolic murmur was attributed to the high cardiac index $\left(6 \cdot 2 \mathrm{l} / \mathrm{min} / \mathrm{m}^{2}\right)$.

Although a diagnosis of hepatic fascioliasis had not been fully substantiated, his deteriorating condition seemed to warrant a trial of specific therapy for this condition and he was given a course of emetine hydrochloride. Over the next 18 months the hepatic failure lessened and his effort tolerance improved. Dietary restrictions and neomycin therapy were withdrawn and he had no recurrence of encephalopathy. The total serum bilirubin fell to $7.5 \mathrm{mg} / 100 \mathrm{ml}$ and the serum albumin level rose, although varying widely from month to month $(2 \cdot 0-3 \cdot 5)$. 


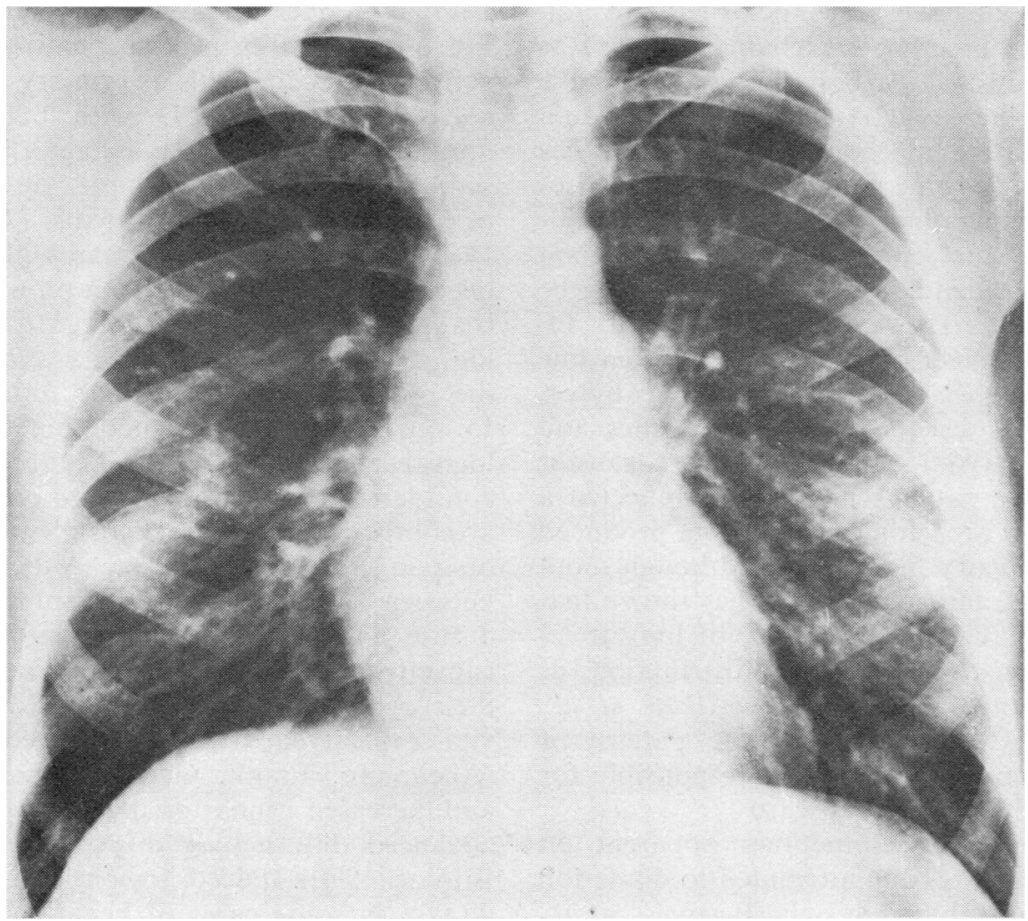

FIG. 7. Case 1. Chest radiograph May 1970. The nodular shadows and increased peripheral vascular markings are no longer present. The hilar vascular shadows are less prominent than previously.

He was readmitted in May 1970 for further cardiopulmonary investigation and the findings are shown in Table IV. The arterial $\mathrm{O}_{2}$ tension had risen somewhat, together with a reduction of the elevated $\mathrm{A}-\mathrm{aDO}_{2}$ breathing air. Furthermore, the level of venoarterial admixture had fallen to within normal limits. Both cardiac index and pulmonary artery pressure were lower than previously. The chest radiograph (Fig. 7) no longer showed basal nodular shadowing or increased peripheral vascular markings and the hilar vascular shadows were less prominent. The TF had not improved and it seemed likely that the remaining hypoxaemia was largely due to ventilation-perfusion inequality, which may also occur in cirrhosis, as described by Cotes et al. (1968). The pulmonary hypertension, although extensively documented in liver cirrhosis (Senior et al., 1968), remains unexplained.

\section{DISCUSSION}

Since pulmonary gas transfer has often been regarded as normal in liver disease, we have reviewed the measurement of transfer factor in hepatic cirrhosis given by other workers. Reduced TF has been found in five previous cases studied by the single breath method (Karlish et al., 1967; Cotes et al., 1968; El Gamal et al., 1970). The steady state TF was also very low in one out of five cases reported by Blackburn et al. (1960). Using the hypoxic breathing procedure the transfer factor for oxygen has been calculated in 27 cases (Williams, 1960; Heinemann, Emirgil and Mijnssen, 1960; Abelmann, Kramer, Verstraeten, Gravallese, and McNeely, 1961; Chiesa, Ciappi, Balbi, and Chiandussi, 1969): among these were eight with values below $15 \mathrm{ml} / \mathrm{min} / \mathrm{mmHg}$, which has been given as the lower limit of normal (Comroe et al., 1962). Thus our values of transfer factor agree with earlier data, and the occurrence of impaired gas transfer in CLD seems well established. In cases of CLD without ascites a decreased TF is not usually associated with any restrictive ventilatory defect. This contrasts with most lung diseases in which a decreased TF tends to be accompanied by a small vital capacity. The 
level of TF provided a useful index of the overall efficiency of pulmonary gas exchange in CLD as cases with diminished carbon monoxide uptake usually had an increased $\mathrm{A}-\mathrm{aDO}_{2}$ breathing room air. Several possible mechanisms may limit gas transfer in CLD. In some patients anaemia reduces the mass of haemoglobin in the pulmonary capillaries available for combination with carbon monoxide. Coincidental lung disease may be present in others. However, the level of TF corrected for the effect of anaemia was often low when lung disease was not apparent clinically or, in two cases, at subsequent necropsy. Cotes and his colleagues (1968) suggested that transfer limitation in their patients might have reflected a decreased surface area for gas exchange produced by uneven pulmonary blood flow. Although more recent work with radioactive xenon has shown that the predominant regional inequality of lung function in cirrhosis resides in the distribution of ventilation rather than blood flow (Ruff et al., 1971), it remains possible that some pattern of pulmonary inhomogeneity may be responsible for the reduction of TF in liver disease.

The basal nodularity sometimes apparent on chest radiography has been attributed to dilatation of small pulmonary blood vessels (Berthelot et al., 1966); this would also be in keeping with the observed accentuation of vascular markings. The high cardiac outputs giving increased pulmonary flow rates in the cases with nodular shadows provided an additional reason for their increased vascular plethora. A physiological consequence of this pulmonary vasodilatation was increased venoarterial admixture, presumably due to opening of multiple intrapulmonary arteriovenous anastomoses. The increased venoarterial admixture, hyperkinetic circulation, and finger clubbing often seen in the cases with radiographic shadows may be concurrent manifestations of a generalized vasodilated state in CLD (Stanley and Woodgate, 1971). It is thus of special interest that all these signs regressed in one patient during a period of clinical improvement. Remission of cyanosis due to intrapulmonary shunting in liver disease has previously been reported in a child (Silverman, Cooper, Moller, and Good, 1968) and it appears that at least some of the circulatory changes caused by CLD are not immutable. Alternatively, the radiographic nodularity could be related to interstitial oedema; this has been suggested as the cause for hypoventilation of the dependent lung zones found with radioactive xenon in hepatic cirrhosis (Ruff et al., 1971). However, true Kerley B lines were not seen in any of our cases with nodularity.
Finally, one clinical aspect must be stressed. Fibrosing alveolitis is occasionally accompanied by active chronic hepatitis or primary biliary cirrhosis, and in cases of CLD with both radiographic mottling and reduced TF a diagnostic problem may sometimes arise. For example, the first case report of CLD with a low single breath TF (Karlish et al., 1967) concerned a young man with active chronic hepatitis: his chest radiograph showed nodular shadowing which was initially attributed to fibrosing alveolitis, but precapillary vasodilatation was the only pulmonary disorder found at necropsy. In our cases with this combination of physiological and radiographic disturbances we have considered the overall picture to be unlike fibrosing alveolitis, but without histological proof this opinion must be guarded. Although differences between CLD with radiographic mottling and diffuse lung disease in the measurements of vital capacity and venoarterial admixture were observed, their clinical importance is probably limited. The vital capacity in CLD may be reduced by ascites (Abelmann, Frank, Gaensler, and Cugell, 1954) and increased venoarterial admixture may occur in advanced diffuse lung disease (Arndt, King, and Briscoe, 1970). Indeed, the exclusion of pulmonary disease in some cases of hepatic disease may not be possible without lung biopsy, which may be hazardous due to coagulation deficiencies. It is thus fortunate that our necropsy material confirms that the incidence of fibrosing alveolitis in CLD is truly rare.

We wish to thank Professor Sheila Sherlock for permission to study patients under her care and Dr. Frances Gardner for allowing us to use the equipment of the Department of Cardiology. Also we gratefully acknowledge the skilled technical assistance given by Mr. Donald Wagstaff, Mrs. Carol Shaw, and Miss Harriet Copperman.

\section{REFERENCES}

Abelmann, W. H., Frank, N. R., Gaensler, E. A., and Cugell, D. W. (1954). Effects of abdominal distention by ascites on lung volumes and ventilation. Arch. intern. Med., 93, 528.

, Kramer, G. E., Verstraeten, J. M., Gravallese, M. A., and McNeely, W. F. (1961). Cirrhosis of the liver and decreased arterial oxygen saturation. Arch. intern. Med., 108, 34 .

Arndt, H., King, T. K. C., and Briscoe, W. A. (1970). Diffusing capacities and ventilation: perfusion ratios in patients with the clinical syndrome of alveolar capillary block. J. clin. Invest., 49, 408.

Berthelot, P., Walker, J. G., Sherlock, S., and Reid, L. (1966). Arterial changes in the lungs in cirrhosis of the liverlung spider nevi. New Engl.J. Med., 274, 291. 
Blackburn, C. R. B., Read, J., McRae, J., Colebatch, H. J., Playoust, M. R., and Holland, R. A. B. (1960). Venoarterial shunting of blood in chronic liver disease. Austr. Ann. Med., 9, 204.

Chiesa, A., Ciappi, G., Balbi, L., and Chiandussi, L. (1969). Role of various causes of arterial desaturation in liver cirrhosis. Clin. Sci., 37, 803.

Chrispin, A. R., and Lessof, L. (1965). The chest radiograph in 'juvenile' cirrhosis (active chronic hepatitis). Brit. $J$. Radiol., 38, 685.

Comroe, J. H., Forster, R. E., DuBois, A. B., Briscoe, W. A., and Carlsen, E. (1962). The Lung, 2nd ed., p. 324. Year Book Medical Publishers, Chicago.

Cotes, J. E. (1968). Lung Function, 2nd ed. Blackwell Scientific Publications, Oxford.

—, Field, G. B., Brown, G. J. A., and Read, A. E. (1968). Impairment of lung function after portacaval anastomosis. Lancet, $1,952$.

Dinakara, P., Blumenthal, W. S., Johnston, R. F., Kauffman, L. A., and Solnick, P. B. (1970). The effect of anemia on pulmonary diffusing capacity with derivation of a correction equation. Amer. Rev. resp. Dis., 102, 965.

El Gamal, M., Stoker, J. B., Spiers, E. M., and Whitaker, W. (1970). Cyanosis complicating hepatic cirrhosis. Amer. J. Cardiol., 25, 490.

Heinemann, H. O., Emirgil, C., and Mijnssen, J. P. (1960). Hyperventilation and arterial hypoxemia in cirrhosis of the liver. Amer. J. Med., 28, 239.

Jones, R. S., and Meade, F. (1961). A theoretical and experimental analysis of anomalies in the estimation of pulmonary diffusing capacity by the single breath method. Quart. J. exp. Physiol., 46, 131.

Karlish, A. J., Marshall, R., Reid, L., and Sherlock, S. (1967). Cyanosis with hepatic cirrhosis: a case with pulmonary arteriovenous shunting. Thorax, 22, 555.
Kowalski, H. J., and Abelmann, W. H. (1953). The cardiac output at rest in Laennec's cirrhosis. J. clin. Invest., 32, 1025.

Mason, A. M. S., McIllmurray, M. B., Golding, P. L., and Hughes, D. T. D. (1970). Fibrosing alveolitis associated with renal tubular acidosis. Brit. med. J., 4, 596.

Ogilvie, C. M., Forster, R. E., Blakemore, W. S., and Morton, J. W. (1957). A standardized breath holding technique for the clinical measurement of the diffusing capacity of the lung for carbon monoxide. J. clin. Invest., 36, 1.

Ruff, F., Hughes, J. M. B., Stanley, N., McCarthy, D., Greene, R., Aronoff, A., Clayton, L., and Milic-Emili, J. (1971). Regional lung function in patients with hepatic cirrhosis. J. clin. Invest., 50, 2403.

Rydell, R., and Hoffbauer, F. W. (1956). Multiple pulmonary arteriovenous fistulas in juvenile cirrhosis. Amer. J. Med., 21, 450.

Senior, R. M., Britton, R. C., Turino, G. M., Wood, J. A., Langer, G. A., and Fishman, A. P. (1968). Pulmonary hypertension associated with cirrhosis of the liver and with portacaval shunts. Circulation, 37, 88.

Silverman, A., Cooper, M. D., Moller, J. H., and Good, R. A. (1968). Syndrome of cyanosis, digital clubbing, and hepatic disease in siblings. J. Pediat., 72, 70.

Stanley, N. N., and Woodgate, D. J. (1971). The circulation, the lung, and finger clubbing in hepatic cirrhosis. Brit. Heart J., 33, 469.

Turner-Warwick, M. (1968). Fibrosing alveolitis and chronic liver disease. Quart. J. Med., 37, 133.

Vanamee, P., Poppell, J. W., Glicksman, A. S., Randall, H. T., and Roberts, K. E. (1956). Respiratory alkalosis in hepatic coma. Arch. intern. Med., 97, 762.

Williams, M. H. (1960). Hypoxemia due to venous admixture in cirrhosis of the liver. J. appl. Physiol., 15, 253. 